\title{
The Sale-of-Control Premium: The Disposition
}

\author{
David Cowan Bayne, S.J.*
}

When C. Russell Feldmann accepted a 2.1 million dollar premium to hand over the Newport Steel board to the Wilport Syndicate, he opened a Pandora's box of sale-of-control questions-questions far from answered, in spite of the Perlman $v$. Feldmann $n^{1}$ court's creditable attempt and historic acclaim. True, the "now famous case of Perlman v. Feldmann"' is justly "celebrated," and deserves its praise as a "judicial landmark." Nonetheless, the court never really did get all the questions back in the box. What should become of the 2.1 million dollar premium? Must it be disgorged? Why? If so, to whom does it go? To the corporation? To the innocent shareholders alone? And always, why? These final crucial questions were too elusive for the Feldmann court, and in the end it failed, and thoroughly so.

The court's failure in the end is all the more poignant because of its effective reasoning in the beginning. On the basic control problem the court shone. Nearly 15 years later Perlman v. Feldmann remains the best judicial statement of fundamental sale-of-control philosophy.
"Directors of a business corporation act in a strictly fiduciary capacity. Their office is a trust. . . They must not, in any degree, allow their official conduct to be swayed by their private interest. . . ." [T] he same rule should apply to his fiduciary duties as majority stockholder, for in that capacity he chooses and controls the directors, and thus is held to have assumed their liability.

From these premises the court reasoned to the illegitimacy of the premium, and concluded: "[W]e think it sound law that a fiduciary may not appropriate to himself the value of this premium." ${ }^{\prime 6}$ Thus has

* Professor of Law, University of lowa.

1. Perlman v. Feldmann, 219 F.2d 173 (2d Cir.), cert. denied 349 U.S. 952 (1955), rev'g 129 F. Supp. 162 (D. Conn. 1952).

2. Berle, "Control" in Corporate Law, 58 CoLum. L. Rev, 1212, 1214 (1958).

3. Andrews, The Stockholder's Right to Equal Opportunity in the Sale of Shares, 78 HARV. L. REv. 505, 506 (1965).

4. Jennings, Trading in Corporate Control, 44 CAL1F. L. REv. 1 (1956).

5. 219 F.2d at 176. The quotation is from Schemmel v. Hill, 91 lnd. App. 373, 385, 169 N.E. 678,682 (1930).

6. 219 F.2d at 178 . 
the Feldmann court enunciated in embryo the custodial concept of corporate control. For such prescience its credit should never be minimized.

But Perlman v. Feldmann has not outlived its usefulness by any means. Granted, it is old. Its contribution to the elemental control principles has been made. It has been analyzed to shreds. But these analyses have never extended beyond the elementals to the court's intricate apportionment of the 2.1 million dollar premium. Yet here remains a stinging goad to further exploration. Perlman v. Feldmann has left the subtlest premium problems unsolved.

Writing during the first surge of control comment in 1958, Berle was right: "The phenomenon of 'control' is perhaps the most important single fact in the American corporate system." He was further right that "[c]orporation law has never surrounded this phenomenon."' But the ten years since have in fact seen much of that phenomenon surrounded.

This "surrounding" process, however, has been a tortuous one and is far from completed. Even today a sizable segment of courts ${ }^{0}$ and commentators ${ }^{10}$ still holds adamantly with the Court of Appeals for the Second Circuit, in Essex Universal Corporation v. Yates, ${ }^{11}$ that the "premium from the sale of a controlling block of stock"'12 is perfectly licit. In mid-1968 Christophides v. Porco ${ }^{13}$ out-Essexed Essex (understandably, perhaps, since in the same circuit): "[A] purchaser is free to offer a premium for a block of control stock. This is so, even though control stock is purchased pursuant to a plan to acquire the remainder of the shares at a lower price . . .' '14 Federal Judge Nordbye was unconcerned over the propriety of a 2 million dollar control premium in Honigman v. Green Giant Company. ${ }^{15}$ Chancellor Seitz put the matter more colorfully in Manacher $v$. Reynolds:" "No other factor being present, they may demand a reasonable premium for the use of their key ... with which to unlock the 'discount'

7. Berle, supra note 2 , at 1212 .

8. Id.

9. See. e.g. Christophides v. Porco, 289 F. Supp. 403 (S.D.N.Y. 1968); Perlman v. Feldmann, 129 F. Supp. 162 (D. Conn. 1952); Manacher v. Reynolds, 39 Del. Ch. 401, 165 A.2d 741 (1960); Stanton v. Schenck, 140 Misc. 621, 251 N.Y.S. 221 (Sup. Ct. 1931).

10. See, e.g., Hill, The Sale of Controlling Shares, 70 HARv. L. REV. 986 (1957).

11. 305 F.2d 572 (2d Cir. 1962).

12. Id. at 576.

13. 289 F. Supp. 403 (S.D.N.Y. 1968).

14. Id. at 405 .

15. 208 F. Supp. 754 (D. Minn. 1961), affd, 309 F.2d•667 (8th Cir. 1962), cert. denied, 372 U.S. 941 (1963).

16. 39 Del. Ch. 401,165 A.2d 741 (1960). 
treasure chest. . . .'17 This same Delaware court gave a capsule statement of the substantial sentiment condoning a control premium:

As to the Perlman case, which made such an impact on the legal fraternity, . . . I can only express a preference for the dissent's view that the increment in stock value arising from control belongs to the sellers, absent some breach of duty. 1 say this because I am satisfied that a practical decision on this issue has been in existence in the business community for too many years for a court to upset it. ${ }^{18}$

That was 1960. As if seconding Chancellor Seitz with a thunderous "aye," the "business community" in the late sixties has broken out in a rash of apparent premiums, confirming its "practical decision on this issue." Shearson, Hammill and E. M. Warburg "gained control" of Silvray-Litecraft while "Messrs. Gilbert and Gordon received $\$ 137,000$ each to resign their posts." ${ }^{19}$ Cyrus Eaton, the Cleveland industrialist, sold his stock block in Detroit Steel for 3.3 million dollars over market as he handed over control of his board seats to Jakob Isbrandtsen and the American Export interests. ${ }^{20}$ But the exemplar for the period and the baldest instance to date was the repartee between A. King McCord, chairman of Westinghouse Air Brake Co., and his opposite number at Crane, Thomas Mellon Evans.

Mr. McCord told his stockholders that Crane chairman T. M. Evans promised "that 1 would receive an option to purchase Crane stock and benefits after retirement, possibly by a consulting arrangement." The Wabco executive also told a court that the stock options dangled before him "might, in 10 years, be worth $\$ 200,000$ or $\$ 300,000$ to me." He added, "I was shocked . . . . I told him (Mr. Evans) that it was entirely improper and that I did not wish to discuss this any more."

Mr. Evans quipped afterward: "I guess (the offer) wasn't inappropriate enough.' ${ }^{21}$

Set off against this "practical decision"-both business and judicial-runs a long thin line of cases, before and after Feldmann, holding otherwise. As early as 1856, an English chancellor handed down the prototype for all times, Sugden $v$. Crossland." "This is a very extraordinary case .... I do not remember a case where the

17. Id. at 423,165 A.2d at 754 .

18. Id. at $418,165 \mathrm{~A} .2 \mathrm{~d}$ at $75 \mathrm{I}$ (emphasis added).

19. Wall Street Journal, Nov. 2, 1967, at 4, col. 3 .

20. Wall Street Journal, Mar. 27, 1968, at 4, col. I.

21. Wall Street Journal, Aug. 28, 1968, at I, col. 6 .

22. $3 \mathrm{Sm}$. \& G. 192, 65 Eng. Rep. 620 (V.C.C. 1856). Sugden was the first instance in Anglo-Saxon jurisprudence of a clearcut premium-bribe for the sale of control. 
office of a trustee has been purchased for money .... I shall therefore direct that the \pm 75 be repaid by Horsfield and dealt with as a part of the [trust] assets." ${ }^{23}$ At the turn of the century the New York court of appeals had resort to Sugden in McClure v. Law and ordered the 15,000 dollar premium-bribe returned to the corporation. Two years later Bosworth v. Allen ${ }^{25}$ confirmed McClure. The line continued in Pennsylvania in 1914 with the oft-cited Porter $v$. Healy ${ }^{26}$ and in New York in 1941 with the famous Reynolds trilogy ${ }^{27}$ (the same family and the same gambit 20 years before Manacher $v$. Reynolds ${ }^{28}$ ). Toward the end of the line, in 1964-again in New York and two years after Essex Universal ${ }^{29}$ - the court of appeals retrod the ground of McClure and Bosworth in the Lionel litigation, ${ }^{30}$ even though it nearly choked on Essex in the process. The lower court saw clearly "that the premium price ... paid for the accompanying transfer of managerial control . . . was the all important emolument of the transaction." 31 This was "in violation of the clear mandate of McClure v. Law . . . . [A]ny bonus received for such transfer of their office [must] be returned to the corporation.' '32

This judicial deadlock over control essentials, let alone the specifics of premium disposition, can never be approached without resort to the philosophy underlying both. Certain fundamentals can prepare the way.33

23. Id. at 193, 65 Eng. Rep. at 622 .

24. 161 N.Y. 78, 55 N.E. 388 (1899).

25. 168 N.Y. 157,61 N.E. 163 (1901).

26. 244 Pa. 427,91 A. 428 (1914).

27. Gerdes v. Reynolds, 28 N.Y.S.2d 622 (Sup. Ct. 1941); Ballantine v. Ferretti, 28 N.Y.S.2d 668 (Sup. Ct. 1941); Gerdes v. Reynolds, 30 N.Y.S.2d 755 (Sup. Ct. 1941).

28. 39 Del. Ch. 401,165 A.2d 741 (1960).

29. 305 F.2d 572 (2d Cir. 1962).

30. There are two distinct Lionel cases. The first was an action to set aside the election of Lionel directors. In re Lionel Corp., 151 N.Y.L.J., Feb. 4, 1964, at 14, col.3 (Sup. Ct.) (Schweitzer, J.) (commonly known as In re Caplan), aff'd sub. nom. Caplan v. Lionel Corp., 20 App. Div. 2d 30I, 246 N.Y.S.2d 913 (1964), affd mem., 14 N.Y.2d 679, 198 N.E.2d 908, 249 N. Y.S.2d 877 (1964). All three courts agreed that the election was illegal. The second case, Gabriel, was a derivative action to recover for Lionel the premium received by Defiance Industries, Inc. in the transfer of control. Gabriel Indus., Inc. v. Defiance Indus., Inc., 151 N.Y.L.J., June 17, 1964, at 13, col. 8 (Sup. Ct.) (Serafite, J.), affd, 23 App. Div. 2d 630, 257 N.Y.S.2d 565 (1965), aff d, 22 N.Y.2d 405, 239 N.E.2d 706, 293 N.Y.S.2d 65 (1968). The first case is referred to hereinafter as Caplan-Lionel.

31. In re Lionel Corp., 151 N.Y.L.J., Feb. 4, 1964, at 14, col. 3 (Sup. Ct.).

32. Id.

33. This study of the control premium is substantially dependent on the custodial concept of corporate control first presented in Bayne, $A$ Philosophy of Corporate Control, $112 \mathrm{U}$. PA. L. REv. 22 (1963) and developed in a series of seven later articles and a book revicw: Bayne, The Sale-of-Control Preniun: The Intrinsic Illegitimacy, 47 TEXas L. REv. 215 (1969); 
Begin with the ultimate postulate in the control hypothesis: The absolute separation of ownership from control. ${ }^{34}$ Whoever the owners may be, no matter. Whoever the controleur, no matter. To this controleur the owners have entrusted complete dominion over their corporation. By this appropriation the owners have constituted the controleur the top policymaking authority in the corporate hierarchy His is the last word. He is by definition untrammeled and unfettered. If not, another is the controleur and this other thereby becomes the subject of discussion. Or, if the owner reassumes dominion, the control hypothesis falls and the discussion ends (then perhaps the corporation itself could be sold, but not control).

This control/ownership dichotomy is an invariable postulate. If the controleur happens also to be an owner-appropriator, with his own share in his own "custody" (a literal impossibility since one may have custody only over another's goods), he yet remains custodian of the others' share. Thus Roy Cohn, controleur, with only three percent of Lionel, was nonetheless a true custodian of the public-held 97 percent. Moreover under the entity theory he could correctly but loosely be called the custodian of the whole. Certainly he is the controleur.

The illation is logical from total dominion to total responsibility. The corporation with all its assets is totally dependent on the controleur. This helplessness begets corresponding responsibility. The controleur, in willingly assuming control, willingly agrees to account for his stewardship. With dominion comes, willy-nilly, the onus of the office: To prosecute unreservedly the collective welfare of corporation and shareholders. In a word, the controleur becomes a strict trustee, ${ }^{35}$ with all resultant rights and obligations-a full commitment to the welfare of the beneficiaries.

This broad fiduciary duty of the controleur has been broken down into (1) The best possible corporate structure, (2) the most

Bayne, The Sale of Control Premium: The Definition, 53 Minn. L. Rev. 485 (1969); Bayne, Book Review, 35 FordhaM L. Rev. 398 (1966); Bayne, A Legitimate Transfer of Control: The Weyenberg Shoe-Florsheim Case Study, 18 Stan. L. Rev. 438 (1966); Bayne, The Sale-ofControl Quandary, 51 CoRnell L.Q. 49 (1965); Bayne, The Sale of Corporate Control, 33 Fordhan L. Rev. 583 (1965); Bayne, The Definition of Corporate Control, 9 St. Louis U.L.J. 445 (1965); Bayne, Corporate Control as a Strict Trustee, 53 Geo. L.J. 543 (1965).

The present article is itself the third of a new series analyzing the sale-of-control premium from the strictly legal (in contradistinction to the factual) aspect. This series will successively treat: (1) The Investment Value of Control Stock, (2) The Sale-of-Control Premium: The Damages, (3) The Suitability of the Successor Controleur, and (4) Cheff v. Mathes and the Reverse Premium-Bribe.

34. The controleur may be an owner but qua owner he is not in control.

35. See Bayne, Corporate Control as a Strict Trustee, 53 Geo. L.J. 543 (1965). 
enlightened managerial policy, (3) the most competent personnel. ${ }^{30}$ Obviously the third of these subduties is the focus of the sale-ofcontrol problems, and more pertinently the disposition of the premium.

Strictly, therefore, corporate control is not a "corporate asset, " 37 not certainly "personalty" 38 or even merely a "function," 39 but rather a "relation of total custody, subsisting between the office of the controleur and the corporation, giving rise to a complexus of duties and a corresponding complexus of rights. '40

Another truism is helpful in reaching the right perspective. Every transfer of control entails simply the choice of a new man for the top job. Feldmann chose Wilport to run Nevport. Roy Cohn appointed Muscat controleur at Lionel. Muscat in turn selected Sonnabend as his successor. Note further: The sale of control is merely a transfer of control-for a price. At Weyenberg Shoe, old man Weyenberg simply transferred control to young Florsheim, without more.41 But Feldmann exacted a 2.1 million dollar premium-bribe to appoint Wilport to the office.

The conjunction of these fundamentals leads to obvious summary conclusions. To fulfill the fiduciary duty of his office the outgoing contoleur must: (1) Consult the broad collective welfare of the corporation by (2) selecting the best possible personnel, in this case his successor, and (3) verifying in this appointee the requisite intellectual, moral, managerial, social and physical ${ }^{42}$ qualities. At the time of the transfer the broad fiduciary duty of corporate control specifies itself into one narrow obligation: To appoint a successor for only one reason, suitability. This is the sole norm of the legitimacy of the transfer.

In this perspective the chief question set for answer is sharply lined. How handle a 2.1 million dollar premium passing to an incumbent controleur from a would-be Wilport?

This broad question and its many subsidiaries will be approached in four stages: 1. The Feldmann Disposition, 11. The State of the Law, III. The Philosophical Foundation of.the Disposition, IV. The Distribution on Disposition.

36. Bayne, A Philosophy of Corporate Control, 112 U. PA. L. Rev. 22, 43 (1963).

37. Berle, supra note 2, at 1221; see A. Berle \& G. Means, The Modern Corporation and Private Property 244 (1932).

38. Essex Universal Corp. v. Yates, 305 F.2d 572, 575 (2d Cir. 1962).

39. Berle, supra note 2, at 1215 .

40. Bayne, The Definition of Corporate Control, 9 St. Lours U.L.J. 445, 446 (1965).

41. Bayne, A Legitimate Transfer of Control: The Weyenberg Shoe-Florsheim Case Study, 18 Stan. L. Rev. 438, 439-42 (1966).

42. See Bayne, The Sale of Corporate Control, 33 Fordham L. Rev. 583, 593 (1965). 


\section{THE FELDMANN DISPOSITION}

The Feldmann facts are familiar and few, but a brief review is essential to this analysis. A group of Newport's customers was hard pressed during the Korean War to keep an inventory of steel. Eyeing a possible captive supply, they approached $C$. Russell Feldmann, the controleur of the Cincinnati-area firm, with the thought "of the sale ... of [the] controlling interest in the corporation." ${ }^{\prime 3}$ "The result: Feldmann, family and friends transferred to the Wilport Syndicate the "control block of stock," 4 at 20 dollars per share "although the overthe-counter market price had not exceeded $\$ 12$ and the book value per share was $\$ 17.03$." 45 On remand the district court set "the value of defendants' stock without the appurtenant control over the corporation's output of steel' ${ }^{\prime 46}$ at $\$ 14.67$ per share, aggregating a 2.1 million dollar premium. The further result: "[T]he resignation of [Feldmann's] own board and the election of Wilport's nominees immediately upon consummation of the sale.' ${ }^{\prime 47}$

At trial Judge Hincks held "that the rights involved in the sale were only those normally incident to the possession of a controlling block of shares, with which a dominant stockholder, in the absence of fraud or foreseeable looting, was entitled to deal according to his own best interests. "'48 On appeal the Second Circuit reversed.

From the sale-of-control aspect the Feldmann case is twopronged. Before apportioning the premium to the plaintiffs-done with two-paragraph dispatch-the second circuit had first to find the foundation for the premium illegality. On first face the reasons for illegality are arguably obiter to a treatise on the prcmium disposition itself. But over the years commentators have raised too many doubts about the court's controlling reason for this illegality.9. A resolution of the doubts is not without help to later reasoning about the disposition.

43. Perlman v. Feldmann, 219 F.2d 173, 174 (2d Cir. 1955).

44. Id. at 175 .

45. Id.

46. Id. at 178. See 154 F. Supp. 436, 446 (D. Conn. 1957).

47. 219 F.2d at 175 .

48. Id. See Perlman v. Feldmann, 129 F. Supp. 162, 187-89 (D. Conn. 1952).

49. See Andrews, The Stockholder's Right to Equal Opportunity in the Sale of Shares, 78 HaRv. L. Rev. 505, 514 (1965); Berle, "Control" in Corporate Law, 58 Colum. L. Rev. 1212, 1218-22 (1958); Hill, The Sale of Controlling Shares, 70 HARv. L. Rev. 986, 989-90 (1957); Jennings, Trading in Corporate Control, 44 CALIF. L. Rev. 1, 8-9, 11-13 (1956); Katz, The Sale of Corporate Control, 38 CHI. B. REC. 376, 377-78 (1957); Leech, Transactions in Corporate 


\section{A. The Rationale of the Illegality}

The factual nub of the illegality holding was the so-called Feldmann Plan. During the war Mr. Feldmann had considerably enriched Newport by exacting interest-free prepayments from prospective purchasers-a practice widely reprobated but nonetheless legal. Of course, Wilport as controleur would deal otherwise with Wilport as consumer. On the rationale for this illegality the Feldmann court is undoubtedly a bit confused, but one nonetheless could piece together an understandable and tenable explanation. Even granting some confusion, the Feldmann opinion remains the best judicial statement of fundamental sale-of-control philosophy..$^{50}$

The court's ambivalence caused the confusion. One moment the premium illegality is referable to a bald sale of control. The next, the harm lies in misappropriating "corporate advantages." ${ }_{51}$ Chief Judge Clark's opening paragraph seems to pull in one clear direction:

This is a derivative action brought by minority stockholders of Newport Steel Corporation to compel accounting for, and restitution of, allegedly illegal gains which accrued to defendants as a result of the sale in August, 1950, of their controlling interest in the corporation. ${ }^{52}$

True, these are the allegations of the plaintiffs, but later, and even here, the unadorned sale of control of Newport seems to be the ultimate gravamen of the action. At another point the court says: "The price of $\$ 20$ per share was found by Judge Hincks to be a fair one for a control block of stock." ${ }_{53}$ Thus, the heart of the wrong appears to be the transfer of the "control block" at a premium. Further: "Plaintiffs argue [that] the vendors must account ... for that share of their profit which is attributable to the sale of the corporate power." ${ }_{54}$ Thus far the court seems completely in the McClure, Bosworth, Lionel tradition. The controleur handed over control of Newport by the seriatim resignation of the board for a 2.1 million dollar premium. For this breach of fiduciary duty the premium goes over to the plaintiffs.

But then begins a slight shift of emphasis. No longer is it solely and simply the sale of overall control.

Control, 104 U. PA. L. Rev. 725, $812-14$ (1956); Comment, Sale of Corporate Control and the Theory of Overkill, 31 U. CHI. L. REv. 725, $731-34$ (1964).

50. See text accompanying notes $1-5$ supra.

51. 219 F.2d at 176.

52. Id. at 174 .

53. Id, at 175 .

54. Id. 
Plaintiffs contend that the consideration paid for the stock included compensation for the sale of a corporate asset, a power held in trust for the corporation by Feldmann as its fiduciary. This power was the ability to control the allocation of the corporate product in a time of short supply, through control of the board of directors; and it was effectively transferred in this sale by having Feldmann procure the resignation of his own board and the election of Wilport's nominees immediately upon consummation of the sale.jis

Here is the first intimation of ambivalence. Yet here the court's argument is reducibly unchanged. Thus the condemned malefaction was "the sale of a corporate asset." This asset was "a power held in trust ... the ability to control the allocation of the corporate product." But this "ability to control the allocation" came only "through control of the board of directors." And "it"- which could mean the "ability to control the allocation" or "control of the board"-was "effectively transferred in this sale." The transfer of the "control of the board," of course, would be the sale of overall control. At this stage, therefore, the court is only saying that "the ability to control the allocation" is just one of the many parts of the control whole. Necessarily, the sale of the whole includes the sale of the part.

Midway in the opinion, however, after an enunciation of the most stringent trust obligations, comes a seemingly forthright turnabout.

The actions of defendants in siphoning off for personal gain corporate advantages to be derived from a favorable market situation do not betoken the necessary undivided loyalty owed by the fiduciary to his principal..$^{56}$

Through several paragraphs the court dilates on these "corporate opportunities of whose misappropriation the minority stockholders complain." 57 Notable among them, of course, would be the advantages of the Feldmann Plan. Also, "Newport might have used the period of short supply to build up patronage in the geographical area in which it could compete profitably even when steel was abundant." 58

But the court's final handling of the 2.1 million dollar premium resolved the ambivalence. The ultimate foundation was the sale of control of the entity. No attempt was made to break down, segregate

55. Id. (emphasis added).

56. Id. at 176.

57. Id.

58. Id. at 177. 
and evaluate individually those "corporate advantages to be derived from a favorable market situation." A single lump sum, determined not by the several lost opportunities, but by the value of the control "sold" ("the value of defendants' stock without the appurtenant control" subtracted from the total price of the sale), was awarded for the central malefaction, the sale of control for a price. The court noted that these opportunities "need not have been an absolute certainty in order to support this action against Feldmann" ${ }^{59}$ and hence they were clearly not reduced to an estimable element of the award. Granted, the court certainly saw these "opportunities" in the background, but in the end treated them merely as functions or subpowers of the overall corporate control.

Judge Swan, in his dissent, clearly saw it that way, and equally clearly saw nothing wrong with it.

The controlling block could not by any possibility be shorn of its appurtenant power to elect directors and through them to control distribution of the corporate product. It is this "appurtenant power" which gives a controlling block its value as such block. What evidence could be adduced to show the value of the block "if shorn" of such appurtenant power, 1 cannot conceive, for it cannot be shorn of it. ${ }^{.0}$

The proposals for a premium-disposition rationale advanced in this Article will accept the thesis that Feldmann was held liable for the bald sale of control of Newport for a 2.1 million dollar premium, irrespective of conjectured ingredients, or later uses, of that broad control once transferred. Should one hold tenaciously to the theory of the "misappropriation" of "corporate opportunities," reconciliation with the principles urged herein as governing the disposition nevertheless should be possible.

Whatever the theory of its nature-a sale of sole control or of a congeries of opportunities - the court, quoting Cardozo, ${ }^{61}$ interdicted the malefaction on only one ground, applicable to either theory: "A trustee is held to something stricter than the morals of the market place. Not honesty alone, but the punctilio of an honor the most sensitive, is then the standard of behavior." "'62 "The first principal duty arising from his official relation is to act in all things of trust wholly for the benefit of his corporation." "थ3 Here was the custodial concept of corporate control.

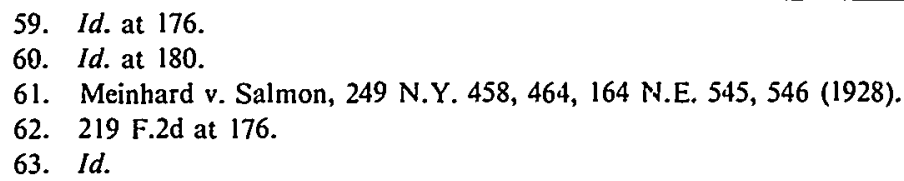


As circuitously as Feldmann may have reasoned to its conclusion, the upshot may be classed-in reference only to sale-ofcontrol fundamentals - as the lineal descendant of Sugden, ${ }^{64}$ McClure, ${ }^{65}$ Bosworth;; ${ }^{\text {;6 }}$ and the progenitor of such as Lionel: "[W]hat occurred here was the mere sale and purchase of naked directorial control . . . in violation of the clear mandate of McClure v. Law." '67 Where Feldmann ranks, beyond the fundamentals, is another matter, the second prong of the case.

\section{B. The Actual Allocation}

Although reasons abounded in support of the premium illegality, the intricate distribution of the 2.1 million dollars was almost perfunctory, without explanation or argument, followed by a summary remand.

The court faced squarely the traditional rule, and understood fully that recovery would normally be in the "right of the corporation (as in the usual derivative actions)." ${ }_{68}$ Judge Clark earlier had adverted indirectly to this rule.

We do not mean to suggest that a majority stockholder cannot dispose of his controlling block of stock to outsiders without having to account to his corporation for profits or even never do this with impunity when the buyer is an interested customer, actual or potential, for the corporation's product. But when the sale necessarily results in a sacrifice of this element of corporate good will and consequent unusual profit to the fiduciary who has caused the sacrifice, he should account for his gain. ${ }^{69}$

But the court determined that a higher law should prevail. Without pro or con, Judge Clark flatly concluded: "Hence to the extent that the price received by Feldmann and his codefendants included such a bonus, he is accountable to the minority stockholders who sue here.' 70 And why not the usual award to the corporation?

[P]laintiffs, as they contend, are entitled to a recovery in their own right, instead of in right of the corporation (as in the usual derivative actions), since neither Wilport nor their successors in interest should share in any judgment which may be rendered.7

64. 3 Sm. \& G. 192, 65 Eng. Rep. 620 (V.C.C. 1856).

65. 161 N.Y. 78, 55 N.E. 388 (1899).

66. 168 N.Y. 157,61 N.E. 163 (1901).

67. 151 N.Y.L.J., Feb. 4, 1964, at 14, col. 5.

68. 219 F.2d at 178.

69. Id.

70. Id.

71. Id. 
The only reason, if it be one, for denying recovery to the corporation was that Wilport "should" not share in the 2.1 million dollars. And why? Nothing beyond the statement.

The court then rationalized a bit-as though perhaps it might be having a slight qualm-by stating the obvious that the Feldmanns "cannot well object to this form of recovery, since the only alternative, recovery for the corporation as a whole, would subject them to a greater total liability." ${ }_{2}$ This, of course, brushed under the rug another, more pertinent, consideration: Whether the Wilport Syndicate, on its part, might "well object to this form of recovery." Nor seemingly did the court consider whether the Feldmanns deserved to be held "to a greater total liability"; perhaps none of the 2.1 mitlion dollar premium belonged to them, let alone a third of it. The distribution was concluded tersety:

The case will therefore be remanded to the district court for a determination of the question expressly left open below, namely, the value of defendants' stock without the appurtenant control over the corporation's output of steel . . . Judgment should go to these plaintiffs and those whom they represent for any premium value so shown to the extent of their respective stock interests. ${ }^{73}$

Judge Swan in his dissent was not so complacent about this allocation of the 2.1 million dollars:

The final conclusion of my brothers is that the plaintiffs are entitled to recover in their own right instead of in the right of the corporation. This appears to be completely inconsistent with the theory advanced at the outset of the opinion, namely, that the price of the stock "included compensation for the sale of a corporate asset." If a corporate asset was sold, surely the corporation should recover the compensation received for it by the defendants. ${ }^{74}$

Of course Swan proved to be as cavalier as Clark, because he also gave no supporting reasons for his disposition. Clark simply said, without more, that Wilport should get no share, and Swan said that Wilport should, without more. Thus is the scene set and the line drawn.

The remand itself conformed to the letter. In a lengthy opinion the court sedulously worked out 'the value of the defendants' stock without the appurtenant control over the corporation's output of steel." ${ }^{\prime 5}$ Broken down, "[t]he vafue of each share of the capital stock

\footnotetext{
72. Id.

73. Id.

74. Id. at 180.

75. Id. at 178.
} 
of Newport Steel Corporation was, on August 31, 1950, \$14.67.'"76 Again, conformably: "The difference between $\$ 14.67$ and the $\$ 20$ per share received by the defendants constituted a premium or bonus paid by Wilport Company for control over Newport's output of steel.'7t

With this, the only remaining chore was the arithmetic to determine Wilport's share-to be kept by the Feldmanns-of the 2.1 million dollars.

The bonuses or premiums of $\$ 5.33$ per share.. . total $\$ 2,126,280.91$. The Wilport Company shares, which are barred by the judgment of the Court of Appeals from recovery in this proceeding, constituted $36.99 \%$ of the outstanding shares of Newport. This percentage of the $\$ 2,126,280.91$ amounts to $\$ 786,511.29$ which, deducted from the $\$ 2,126,280.91$, leaves $\$ 1,339,769.62$ due . . . the present holders ... other than ... the Wilport Company ... in proportion to the number of shares each holds. ${ }^{\text {is }}$

Thus ended the Feldmann distribution of the 2.1 million dollar premium paid by Wilport to Feldmann for control of Newport. The public shareholders received 1.3 million dollars. Feldmann retained the rest. Nothing went directly to the corporation. Wilport lost all.

\section{THE STATE OF THE LAW}

Gleanings of premium-disposition principles can scarce be gathered from the antagonistic line beginning with Barnes v. Brown, ${ }^{79}$ running through Manacher $v$. Reynolds, ${ }^{80}$ Green Giant, ${ }^{81}$ Essex Universal,"2 and culminating in 1968 with Christophides:".3 "These cases hold that a majority or controlling stockholder is under no duty to other stockholders to refrain from receiving a premium upon the sale of his stock which reflects merely the control potential of that stock." 84

But even in those cases where the premium was declared illegal, the judicial contribution to a more refined body of law is sparse

\footnotetext{
76. 154 r. Supp. at 446.

77. Id.

78. Id.

79. 80 N.Y. 527 (1880).

80. 39 Del. Ch. 401,165 A.2d 741 (1960).

81. 208 F. Supp. 754 (D. Minn. 1961).

82. 305 F.2d 572 (2d Cir. 1962).

83. 289 F. Supp. 403 (S.D.N.Y. 1968).

84. Id. at 405 .
} 
indeed. In the majority, the bare rule of Sugden $v$. Crossland ${ }^{85}$ in 1856 was follwed without explanation. Thus it was in 1964 with Lionel: "[A]ny bonus received for such transfer of their office [must] be returned to the corporation." ${ }^{86}$ In fact, without exception-McClure, Bosworth, ${ }^{88}$ Porter v. Healy, ${ }^{89}$ the Reynolds cases $^{90}$-all awarded the premium to the corporation, but, unfortunately, all equally without exception adduced no reasons at all for the award. One might conjecture that the reasons were too patent, that the premium so obviously belonged to the corporation that discussion would be otiose. But some experience of the pain suffered in unravelling the intrinsic illegitimacy of the premium, ${ }^{91}$ and its rightful ownership by the corporation, destroys this conjecture. The judicial silence is perhaps rather referable to the very complexities of this illegitimacy. In any event, resort to the adjudicated cases for a premium-disposition philosophy yields little beyond the bald conclusion that the premium belongs to the corporation, without elaboration.

\section{A. Damages Distinguished}

Somewhat inexplicably, another factor contributed to the judicial fuzziness, or outright silence, on the rationale of the disposition. Rarely did courts segregate the premium-bribe money from any dollar damages for later looting, collateral chicanery, or the harm from disloyalty and conflict of interest. Here are mutually exclusive concepts, one founded in the law of restitution, contract, and trust; the other in tort. A court must approach damages and disposition, therefore, from totally distinct aspects.

Yet, interestingly, only two of the major control cases overtly recognized this distinction. Gerdes $v$. Reynolds,$^{92}$ where palpable looting and a substantial premium-bribe made the distinction clamorous, first ordered over the 1.3 million dollar premium $(\$ 1.25$ per share over the actual value of 75 cents) and then mulcted the Reynolds group 903,000 dollars in damages for injury to Reynolds lnvesting. In Bosworth v. Allen ${ }^{93}$ the approach was equally orderly.

85. 3 Sm. \& G. 192, 65 Eng. Rep. 620 (V.C.C. 1856).

86. 151 N.Y.L.J., Feb. 4, 1964, at 14, col. 5.

87. 161 N.Y. 78,55 N.E. 388 (1899).

88. 168 N.Y. 157,61 N.E. 163 (1901).

89. 244 Pa. 427, 91 A. 423 (1914).

90. Gerdes v. Reynolds, 28 N.Y.S.2d 622 (Sup. Ct. 1941); Ballantine v. Ferretti, 28 N.Y.S.2d 668 (Sup. Ct. 1941).

91. See Bayne, The Sale-of-Control Premium: The Intrinsic Illegitimacy, 47 TExas L. REv. 215 (1969).

92. 28 N.Y.S.2d 622 (Sup. Ct. 1941).

93. 168 N.Y. 157,61 N.E. 163 (1901). 
But in all others the courts addressed one or other question, but never both. In such as Sugden and McClure the oversight was understandable. After the premium was disgorged, the tort damages from disloyalty, the breach of fiduciary duty, were most intangible, even if not minimal. With Lionel, ${ }^{94}$ however, the omission of all mention of damages is somewhat surprising, since the Muscats' disloyalty in selling and Sonnabend's malevolent designs in buying were spread across the opinion. The premium-bribe, of course, was far more obtrusive.

The prime anomaly, however, was Insuranshares Corporation $v$. Northern Fiscal Corporation. ${ }^{95}$ Here the court took exactly the opposite tack. The premium-bribe, not inconsequential (" $t \mathrm{t}] \mathrm{he}$ price is strongly indicative of the true nature of the transaction. The sellers obtained $\$ 3.60$ a share at a time when the price of the stock in the over-the-counter market was $\$ 1$ to $\$ 1.25$, and when the book value was $\$ 2.25$-a figure substantially higher than could have been realized on actual liquidation'"y6), was totally ignored. Thus $\$ 178,442.55$ was overlooked, while damages for the tort harm were fixed at $\$ 207,358.87$. This holding is all the more remarkable since the premium-bribe had been so obviously isolated from the share value of the stock..$^{97}$

An analysis of the premium-bribe disposition must substantially relegate this intrusive question of damages to another time. Such relegation, however, is not uniformly practicable. As the discussion progresses, the impact of a damages award on one's understanding of the philosophy of the apportionment can be great, even though subconscious. But the analysis primarily must concern the disposition and later allocation of the premium-bribe, duly identified and isolated, with damages for elsewhere.

94. 151 N.Y.L.J., Feb. 4, 1964, at 14, col. 3.

95. 35 F. Supp. 22 (E.D. Pa. 1940).

96. Id. at 24.

97. This fact question of the isolation of the premium-bribe handled so easily in Sugden. McClure, Porter v. Healy, and so well in Bosworth, Gerdes. Insuranshares and Lionel has bedeviled many courts-Stanton v. Schenck, 140 Misc. 621, 251 N.Y.S. 221 (Sup. Ct. 1931), Benson v. Braun, 8 Misc. 2d 67, 155 N.Y.S.2d 622 (Sup. Ct. 1956), and Essex Universal in particular-where it never should have. True, the sale-of-control jurist may never fight the facts. The premium-bribe must be proven in isolation or the matter dropped. "One cannot but sympathize with plaintiff's counsel. A great deal of work was done, and doubtless in the best of faith. Still, with all the intricacies and sophistication of modern corporation law, we must remember that it is, after all, a virtue of our system, and not a vice, that the lack of facts remains a vital deficiency." Gottlieb v. Heyden Chemical Corp., 34 Del. Ch. 436, 438, 105 A.2d 461, 462 (1954). 


\section{B. Distribution Upon Disposition}

At this point Perlman v. Feldmann manifests its singular value as a vehicle for the subtlest disposition problems.

Never before did a court question who would share how much of the premium award. Why? In many cases the entire amount was gobbled up, and justly so, by the corporate creditors. Thus in Gerdes v. Reynolds the trustee in bankruptcy claimed the entire premium. Or as with Sugden and McClure, the beneficiaries behind the entity were all deserving innocents. Strictly speaking, Lionel should have offered the same queries as Feldniann, since the premium-bribe money Muscat paid over to Lionel was immediately shared by Sonnabend who had paid it to Muscat in the beginning. The explanation, though not the excuse, for the court's oversight was probably the small amount, three percent, of Sonnabend's share in the 135,000 dollar premium-bribe. But, howsoever explained, the Lionel court never even asked itself whether Sonnabend should share in the illegal premium.

Thus Feldmann stands alone in the judicial history of corporate control as the first and only court to apportion the premium-bribe among the competing parties, rather than, as Lionel, awarding it in toto, without qualification or quaver, to the corporation.

And Feldmann undoubtedly raised every possible issue. First and most fundamental, why assume at all that the premium belongs to the corporation (Feldmann did so assume, even if from a visceral sense)? Why deny Wilport its share? Sonnabend got his. Did Feldmann deserve to keep a third of the 2.1 million dollars? Suppose Feldmann had "sold" control but retained a sixth of the Newport shares, would the court deny both Feldmann and Wilport a sixth of the 2.1 million dollars? Without doubt Perlman v. Feldmann is a stinging goad toward a full philosophy of premium-bribe disposition.

\section{III}

\section{The Philosophical Foundation of the Disposition}

On its path to the final allocation, the Feldmann court began to grope as soon as it progressed beyond the Cardozo trust generalities and the rudiments of the custodial concept of corporate control. Perhaps this is harsh, because, groping or no, several valid proximate, subsidiary conclusions were in fact reached (in contradistinction to the ultimate conclusion of the general liability of Feldmann). And the court did move successfully from the general fiduciary duty to the 
specific liability for the sale of control, even though the intermediate steps were in the dark and the final implementation incorrect. Granted, some rationalization was also required to explain the court's ambivalence in arguing to the naked sale of control. But groping and ambivalence withal, the upshot was nevertheless indisputably in the broad tradition of Sugden, McClure, Gerdes and Lionel.

\section{A. The Premium-Bribe}

Moreover, the later groping among the more proximate principles was not so blind as to be aimless. The court reached three clear-cut and influential conclusions subsidiary to the overall liability of Feldmann. Since every such conclusion must perforce be founded on a controlling principle, one can justifiably (albeit somewhat forcibly) construct a tenable Feldmann philosophy even on this proximate level. In short, the court's actions were far louder than its words.

The conclusions? The first logically and most evident: The corporation was seriously harmed by the Feldmann-Wilport deal and, moreover, the fruits of the deal belonged in justice to the entity. Second but far and away the foremost and most compelling: Wilport's role was seriously reprehensible. The third and last but nonetheless important: The Feldmann culpability was almost as great.

These three together must next be joined to a highly indicative fourth factor. Note that the court was not concerned with damages, but awarded a lump sum from the 2.1 million dollars paid by Wilport to induce Feldmann to hand over the board. Judge Hincks was more forthright in acknowledging this distinction:

In this connection it must be remembered that the plaintiffs frankly are not seeking the recovery of damages for harm done to the corporation by a breach of trust. Instead, plaintiffs rely upon the principle that "a fiduciary who has acquired a benefit by a breach of his duty as fiduciary is under a duty of restitution to the beneficiary," quoting from the Restatement, Restitution, Sec. 138(1).98

Not only was the court attempting a "restitution to the beneficiary" of such "benefit" but in the process it laid down the elementary and obvious formula for the identification and isolation of that "benefit," the premium paid for control. "The case will therefore be remanded to the district court for a determination of . . . the value of defendants' stock without the appurtenant control over the corporation's output of steel." "99 (Furthermore, the lengthy implementation of this directive

98. 129 F. Supp. at 188.

99. $219 \mathrm{~F} .2 \mathrm{~d}$ at 178. 
by the district court is a feasible pattern for a fact-finder in an attempt to segregate the premium in a sale of control.)

The conjunction of these four factors forces the question: What must be the nature of a premium that would lead the court to such drastic conclusions? Or, better: Wherein lay the malefaction in passing such a premium from Wilport to Feldmann? In its three proximate conclusions has not the court unwittingly verified all of the five principal parts for a determination of

the sale-of-control premium-bribe . . . technically defined as (1) some form of consideration ... (2) flowing to the incumbent controleur, (3) from or on behalf of the prospective controleur, (4) to induce the appointment to the office of control, (5) paid knowingly, scienter. ${ }^{100}$

This hypothesis would support each of the three subconclusions. First, from the early days of McClure v. Law and before, courts have uniformly handed over a premium-bribe to the corporation: "The learned Appellate Division has treated this transaction as a bribe paid to the directors of the Life Union by Levy . . . . "'101 Second, a frank description of the deal as premium-bribery would have characterized Wilport's malefaction as sufficiently enormous to fortify two of the court's other three predispositions, namely (1) that the corporation should receive the entire 2.1 million dollars and (2) that Feldmann should disgorge all of it, not merely two-thirds. Third, the assumption that the premium-bribed, Feldmann, is as guilty (or almost, according to the court) as the premium-briber, Wilport, would make good sense out of the order to Feldmann to pay over at least the 1.3 million dollars. In short, the court was torn between the respective culpability of Wilport and Feldmann. Why it decided that the premium-bribed was less guilty than the premium-briber one will never know.

\section{B. The Illegality of the Premium-Bribe}

Even more pervasive was the court's ready realization that this premium-bribe, once identified and isolated, was somehow bad. This, however, is understandable, since most honest citizens, faced with an acknowledged bribe, will reason to its illegality without benefit of complex ratiocination. So it was with the Feldmann court. How far the court could go in dissecting and defining this illegality is a more difficult question. Had the court penetrated through to the niceties, Feldmann probably never would have kept the third of the premium(1969).

100. Bayne, The Sale-of-Control Premium: The Definition, 53 MinN. L. Rev. 485, 497

101. 161 N.Y. at 80,55 N.E. at 389. 
bribe, and Wilport might have got it as a shareholder. But in any event, few of the conclusions would have been reached had not the court sensed that the premium-bribe was somehow illegitimate. How this illegitimacy should have been analyzed is a deeper question.

The philosophical questions yet unanswered and the many nuances remaining will be approached in six distinct steps: (1) The Norms for Disposition, (2) The Turpitude of the Premium-Bribe, (3) The Illicit Consideration, (4) The Law of Restitution, (5) The Shareless Sale, and (6) The Culpability of the Parties.

\section{l. The Norms for Disposition}

The immediate query of the overall disposition is clear. Who gets what? How much? Who loses what? How much? Why? The Feldmann facts have supplied the spare essentials: (1) The round sum of 2.1 million dollars must be placed in the right hands. (2) One malefactor, Feldmann, exacted the premium-bribe from one other, Wilport. (3) Only one party was injured, the corporation, unless the veil is later lifted to look at the shareholders behind. (4) The malefaction was primitive: premium-bribery to induce Wilport's appointment as controleur of Newport.

On first blush, many answers to the query rush forward. The corporation should get all by default-since the guilty premium-bribed should get none, or the equally guilty premium-briber. But that only excludes the guilty, with no positive reasons for the corporate boon. Possibly all should go to the innocent public shareholders? But that would be a windfall. Should a punitive award go to the corporation? Certainly the malefactors should be punished. What of escheat to the state? Perhaps return the money to Wilport? Or let Feldmann keep his share, as the court ordered?

But this immediate query-how to handle the 2.1 million dollars-is superficial indeed. To answer the immediate, one must first answer the ultimate: What is the fundamental norm governing the premium-bribe disposition? Wherein lies the basic rationale for the award of the $\$ 2.1$ million?

The wrong holds the key. To determine who gets what from whom, one must first determine who harmed whom, how and to what extent. From the nature of the wrong can be discerned the nature of the remedy. The wrong is the causal nexus between wrongdoers and wronged. As the injury flowed from malefactors to victim, so also will the restoration. The ultimate determinant of the disposition, therefore, is the causal impact of the wrong. Wilport and Feldmann committed an indivisible moral act, the single act of premium-bribery. $\ln$ the 
essence of this malefaction lie all the ingredients necessary to supply the controlling principles for righting the wrong, for the proper disposition of the 2.1 million dollars. The heart of every wrong is the breach of a duty. But mercly to say "breach of a duty" is only the beginning, because the breach in premium-bribery is a complicatcd breach. Granted, premium-bribery is an indivisible, intentional tort, the breach of the trust obligation of loyalty-the fiduciary duty of the controleur to administer the entity to the exclusive benefit of the beneficiaries-shareholders-but that is too generic (even though the constituents of the tort are only rationally separable). Why? Because the rationale for the disposition might well be founded on less than the total tort, on only one or more of its conceptual parts. To what extent, how much or how little, can the overall Wilport-Feldmann deal be directly related to the 2.1 million dollars? Were only some aspects of the undivided breach specifically responsible for the premium-bribe? In such close reasoning, cause cannot be greater than effect, or lesser. Only a deeper analysis of the Wilport-Feldmann breach, therefore, will yield the formula for the premium-bribe disposition.

\section{The Turpitude of the Premium-Bribe}

The complexities and involutions of the intrinsic illegitimacy of the tort of premium-bribery are the most challenging and important in the entire control study.102 The early investigation of the atom might be a parallel. On first approach, from the outside, both seem a partless unit, ultimate in simplicity, defying further breakdown. But dig below the surface and a new world lies beneath, parts within parts, relations and subrelations.

The pattern inside the premium-bribe is tripartite. Both principal parties, controleur and successor, were guilty simultaneously of (1) passing illicit consideration (2) in the appointment of an unsuitable successor (3) thereby perverting the judgment of selection. These elements coalesce to constitute the total turpitude of the premiumbribe, technically defined as

(1) the perversion of the judgment of the incumbent controleur, engendered by an appointment of a successor induced by a cause other than suitability, (2) that is, for consideration illicit in itself, (3) resulting in the appointment of a candidate unsuitable by reason of his own active role in the inducement. ${ }^{103}$

102. See Bayne, supra note 91 , at 216 .

103. Id. at 222. 
The three elements derive their illegitimacy from various violations of fiduciary duty. As fully compensated corporate custodians, one an incumbent and one an appointee but both nonetheless committed, each had espoused the corporate welfare, particularly in the choice of a new leader. At that electric instant when incumbent passed control to appointee, only one norm could be consonant with corporate well-being: the suitability of the successor. When each agreed, therefore, to an appointment for a motive other than successor suitability, here cold cash, the result was triple-the illiceity of the consideration, the perversion of the judgment of selection and, subtly, the appointment of a successor who became unsuitable by his very act of premium-bribery. Here, in fine, is the threefold essence of premium-bribe illegitimacy.

\section{The Illicit Consideration}

The joint and indivisible act of Wilport and Feldmann was solely responsible for the premium-bribe. The resultant 2.1 million dollars must be specifically referable to one, two or all three of the conceptual coconstituents of this malefaction. In such constituents, therefore, will be found the rationale for the disposition of the 2.1 million dollars. But which of the three relate to the money? The answer can be reached both negatively by the process of elimination and positively by proof of actual causal impact.

(a) The Perversion Elininated.-Controleur Feldmann appointed Wilport for 2.1 million dollars, a motive "totally irrelevant, foreign, antagonistic to"'104 the sole legitimate norm, successor suitability. The consequent perversion of judgment undeniably became the principal constituent of the total turpitude of the tort. Should not one immediately conclude, therefore, that this principal turpitude is thereby the principal determinant in the disposition of the 2.1 million dollars? To the contrary, whatever other effect it may have, the perversion as such is unrelated to the 2.1 million dollars. A homely analogy can effectively sever the perversion from the illicit cash.

Conceive a highly conceivable situation. The corporation was family-founded, and family-controlled ever since, but the ownership has long been dissipated among thousands. The reigning patriarch, now in his eighties, finally sees need of a successor. Three suitors seek the succession, the brilliantly competitive executive vice-president (long conceded the job), the miserably bereft president (fortuitously, also papa's only son) and an unscrupulously aggressive consumer

104. Id. at 223 . 
syndicate (interestingly, with an under-the-table 2.1 million dollars for the seriatim resignation of the board). Papa is unhesitating. With not a nod to the corporate welfare, his choice has only one basis: paternal prejudice. Here is a perfect perversion. Thoughts of successor suitability never entered the old man's head. The proffered premiumbribe could not have perverted his judgment any more effectively. Yet more to the present point, the perversion had no causal connection with any monetary consideration. Not a single cent changed hands. Thus a perfect perversion may enjoy its full maleficence without any premium-bribe at all. The formula for disposition, therefore, can scarce be found latent in this first of the three constituents.

(b) The Premium-Bribe-Induced Unsuitability.-So also with the second constituent. Imagine a beleaguered corporation, a Chrysler in the Colbert days or a Ford before Breech. Add another factor: The incumbent controleur is not only grossly inept but he is also a New Yorker who knows some law ("[A] majority or controlling stockholder is under no duty to other stockholders to refrain from receiving a premium upon the sale of his stock which reflects merely the control potential of that stock"105). On to this scene walks a minority stockholder with a perfect candidate for successor, and minimal qualms about passing a bribe. The suitable successor is the guiding genius of a competitor. He is, furthermore, completely oblivious of the backroom negotiations and is satisfied with his sizable salary and the opportunity to turn the corporation around. The deal is sealed. The 2.1 million dollars passes from the minority Robin Hood to the outgoing controleur. The result? A perfectly suitable successor, unsullied by even the tincture of a bribe.

This little story makes it obvious, therefore, that some rationale other than the premium-bribe-induced unsuitability must determine the disposition of the 2.1 million dollars. That question remains unsolved. Thus a 2.1 million dollar bribe can effectively pass without any relation to premium-bribe-induced unsuitability. The explanation must lie elsewhere.

(c) The Ultimate Rationale.-With both perversion and successor unsuitability removed from the rationale, the third coconstitucnt could carry the day by default. Positive argumentation, however, can establish "the all important emolument of the transaction" ${ }^{106}$ as the controlling constituent of the triple turpitude. Without support or influence from either perversion or unsuitability, the illicit consideration alone can answer who gets what and how much.

105. Christophides v. Porco, 289 F. Supp. 403, 405 (S.D.N.Y. 1968).

106. In re Lionel Corp., 151 N.Y.L.J., Feb. 4, 1964, at 14, col. 5. 
The conceptual unity of the tort's turpitude, however, again forces resort to an apposite analogy. The story has been told ${ }^{107}$ of the mythical president of a mythical U.S. Screw and Bolt, Inc. In his early days he did a good job, was well worth his 50,000 dollar salary, and even developed a national name for himself as a formidable banquet speaker and informative good will ambassador for the firm. But soon the speech-making tail began to wag the working dog, and the barnstorming head of Screw and Bolt was netting nearly 20,000 dollars a year in personal income from his junkets.

Here, standing isolated, is one element common to the premium-bribe, unearned recompense, without the perverson of the officer's judgment or any question of an unsuitable successor. The malefaction is a clear case of illicit emolument, without more. The chief executive officer of Screw and Bolt accepted $\$ 20,000$ in compensation for corporate acts, performed pursuant to a corporate program, in fulfillment of a eorporate duty, in the course of official business, during the regular workweek, for which he was already amply remunerated.108

The parallel with the 2.1 million dollars seems unassailable. Thus isolated, both 20,000 dollars and 2.1 million dollars justly belong in the corporate till, and for exactly the same reasons. In both cases "the all important emolument" 109 was paid by a third party, to a top corporate executive, as a corporate official, because of his official position, and pocketed personally, even though every minute of time and ounce of energy had been dedicated to the exclusive benefit of the beneficiary-shareholder. Most important in both cases, the money was paid for the performance of an official corporate act, even though concededly that act was seriously harmful to the corporate well-being.

Join this positive analysis to the negative elimination of the perversion and successor unsuitability. Now the foundation of the disposition has been narrowed to its simplest elements. 1n essence the Wilport-Feldmann fiducial breach-in specific reference to the 2.1 million dollars alone-consisted solely in the unlawful passing and, more to the point, the unlawful retention of that very 2.1 million dollars. Although the total tort has a triple turpitude, only the specific turpitude of the illicit retention is referable to the 2.1 million dollars. Here is the sole rationale of the disposition.

\section{The Law of Restitution}

In rigid logic, the matter of the 2.1 million dollar disposition

107. Bayne, supra note 91 , at 235 .

108. Id.

109. In re Lionel Corp., 151 N.Y.L.J., Feb. 4, 1964, at 14, col. 3. 
could end with a simple tort recovery for misappropriation of corporate funds. Such recovery-even prescinding from the disloyalty in the perversion and the successor unsuitability-could encompass not only (a) the intangible (some would say nebulous) disloyalty damages for accepting any money beyond an agreed salary, but also (b) the actual award of the 2.1 million dollars itself.

But an inherent disability handicaps this simple tort approach. It does not express the whole truth. Feldmann and Wilport were not ordinary tortfeasors-regular employees, selling agents, or low-level corporate officers-they were also fiduciaries who had placed themselves above the "workaday world" on a fiduciary level "stricter than the morals of the marketplace." As trustee tortfeasors Feldmann and Wilport must be regarded with a more refined eye. Theirs are all the custodial obligations of corporate control and particularly of the highly pertinent benefit-to-beneficiary rule.

From another aspect the unqualified tort action is even more inadequate. Concededly the intentional tort of premium-bribery is necessarily the focal (if not the sole) malefaction. But the legal mind can surely discern a second related wrong, distinct from the mere passing and receiving of the 2.1 million dollars. Strictly one might argue that the receipt of the 2.1 million dollars was the last essential act of premium-bribery, and that the retention thereafter constituted a second definable wrong-unjust enrichment.

The illicit retention of corporate funds ("compensation for corporate acts, performed pursuant to a corporate program, in fulfillment of a corporate duty, in the course of official business, during the regular workweek, for which he was already amply remunerated") opens up several traditional avenues to recovery. The Restatement of Restitution suggests one:

In some cases, however, the quasi-contractual action of assumpsit is based wholly upon the unjust enrichment of the defendant. Thus a principal is entitled to a bribe received by his agent from a third person, although the principal's profit from the transaction, aside from the bribe, was the same as it would have been if no bribe had been given (see Restatement of Agency, § 403). "110

But a common law action of assumpsit is encumbered somewhat by the same disability as the simple tort approach. It too ignores the heightened trust obligation of the parties.

The most sophisticated and exacting rationale is the deft blending of restitution with trust, and the conjunction in turn of this blend with

110. Restatenent of Restitution $\S 128$, comment $/$ at 531 (1937). 
the basic tort action. The law of restitution has a long and reliable history and complements admirably the benefit-to-beneficiary rule of trusts.

Where a fiduciary in violation of his duty to the beneficiary receives or retains a bonus or commission or other profit, he holds what he receives upon a constructive trust for the beneficiary."11

In a general way Judge Hincks was alluding to this synthesis when he noted "[T]hat the plaintiffs frankly are not seeking the recovery of damages for harm done to the corporation by a breach of trust. Instead, plaintiffs rely upon the principle that 'a fiduciary who has acquired a benefit by a breach of his duty as fiduciary is under a duty of restitution to the beneficiary . . . .' ',112

In drafting the Restatement, the Committee on Restitution would have readily included corporate premium-bribery within the ambit of their thinking:

\section{Comment:}

a. Bribes and commissions. The rule stated in this Section is applicable not only where the fiduciary receives something in the nature of a bribe given him by a third person in order to induce him to violate his duties as fiduciary, but also where something is given to him and received by him in good faith, if it was received for an act done by him in connection with the performance of his duties as fiduciary. Thus, if a trustee, or corporate officer, or an agent entrusted with the management of property insures the property in a company of which he is an agent, and he receives from the company a commission for placing the insurance, he is accountable for the commission so received and holds it upon a constructive trust for his beneficiary (see Restatement of Trusts, $\S 170$, Comment $n$; Restatement of Agency, $\S 388$, Comment $a) .{ }^{113}$

The philosophy and the reasoning of the Committee is thus far unimpeachable. Their next step, however, encountered a pitfall altogether too common. ${ }^{14}$

c. Where no harm to beneficiary. The rule stated in this Section is applicable although the profit received by the fiduciary is not at the expense of the beneficiary. Thus, where an agent to purchase property for his principal acts properly.in making the purchase but subsequently receives a bonus from the seller, he holds the money received upon a constructive trust for his principal. The rule stated in

111. Id. $\$ 197$.

112. Perlman v. Feldmann, 129 F. Supp. 162, 188 (D. Conn. 1952).

113. RESTATEMENT OF RESTITUTION $\$ 197$, comment $a$ at 808-09 (1937).

114. See Bayne, Corporate Control as a Strict Trustee, 53 GEO. L.J. 543, 580 (1965). 
this Section, like those stated in the other Sections in this Chapter, is not based on harm done to the beneficiary in the particular case, but rests upon a broad principle of preventing a conflict of opposing interests in the minds of fiduciaries, whose duty it is to act solely for the benefit of their beneficiaries. ${ }^{115}$

(This is redolent of the summary award, without explanation or support, of Sugden, McClure, Lionel, et al.) Here manifest is the historical confusion surrounding the prevention-of-temptation argument as an explanation of the conflict-of-interest rule. ${ }^{116}$ True, the prophylactic effects of the rule are healthy, but they are strictly byproducts. The ultimate basis is again the custodial concept of corporate control. In short, the benefit-to-beneficiary "rule stated in this Section" to the contrary is "based on harm done to the beneficiary in the particular case." And the harm in this particular case "[1]s one element common to the premium-bribe, unearned recompense. . . . [F]or corporate acts . . . for which he was already amply remunerated." 117 Denial of such emolument to the beneficiaries would be a very real harm indeed.

Thus the belabored dissection of the intrinsic illegitimacy of the premium-bribe, and the isolation of the illicit consideration from the perversion and the successor unsuitability, were both necessary processes in uncovering the philosophical fundamentals for the disposition of the 2.1 million dollars. These philosophical fundamentals command restoration to the corporation in any view of the matter, whether the approach is simple tort damages or the more enlightened and correct conjunction of the restitution-trust philosophy with the basic tort that originally gave rise to the 2.1 million dollars.

A fiduciary who commits a breach of his duty as fiduciary is guilty of tortious conduct and the beneficiary can obtain redress either at law or in equity for the harm done. As an alternative, the beneficiary is entitled to obtain the benefits derived by the fiduciary through the breach of duty. Situations involving specific breaches of duty with the resultant creation of a constructive trust and an equitable lien in the proceeds in favor of the injured beneficiary are dealt with in $\S \S 190-201 .{ }^{118}$

Thus the intentional tort of premium-bribery is really only rationally distinct from the violation of the benefit-to-beneficiary rule. The same fundamental wrong-retaining illicit consideration-is common to

115. Restatement OF Restitution, §197, comment $\mathrm{c}$ at 809-10 (1937).

116. See Bayne, supra note 114, passim.

117. Bayne, supra note 91 , at 235.

118. Restatement OF Restitution $\S 138$, comment $a$ at 556 (1937). 
both. The double approach to the single wrong, however, reflects reality admirably.

\section{The Shareless Sale}

The human mind often can penetrate more easily an apparently impervious problem if the complexities are first reduced to the absurdity of A, B and C. Just such a reductio of the WilportFeldmann intricacies is McClure v. Law. ${ }^{119}$ The chief glory of McClure is the simplifying absence of all shares and shareholders. The Life Union Association was a mutual life-insurance company. Business was in a flourishing condition and "it seems that one Mr. Louis P. Levy desired for his own purposes to procure the control of' '120 the firm. The controleur, William H. Law, and the rest of the board readily agreed to "the sum of $\$ 15,000$, in consideration, [and] transferred to Levy the full control of the corporation'"121 by the thennovel seriatim resignation of the board.

Stripped of the delicate distribution questions McClure stands apt for analysis. With no shareholders, only three parties were involved: William $H$. Law exacted the premium-bribe from Louis P. Levy for control of Life Union. Beyond the perversion of his judgment and the appointment of a premium-briber to the office of control, the incumbent controleur accepted 15,000 dollars for a corporate act, the most important of his corporate career, performed "in fulfillment of a corporate duty, in the course of official business, during the regular workweek, for which he was already amply remunerated." "122

On these facts a court should readily order over, as the $\mathrm{McClure}$ court did, the entire 15,000 dollars to the corporation. The premiumbriber, Levy, should lose all. The premium-bribed, Law, should disgorge everything. In such simple circumstances the basic philosophical principles are fully operative, unobstructed by minddistracting collateral questions. McClure will be a help betimes.

Note well that the Feldmann court really reached all these conclusions itself. Certainly it would have adjudicated McClure $v$. Law exactly as did the New York court of appeals. With a more gingerly approach to its subtle allocation problems, the Feldmann court might well have gone on to a correct conclusion itself. But from

119. 161 N.Y. 78,55 N.E. 388 (1899).

120. McClure v. Law, 20 App. Div. $459,461,47$ N.Y.S. 84,85 (1897), rev'd, 161 N.Y. 78, 55 N.E. 388 (1899).

121. Id. at 461,47 N.Y.S. at 85.

122. Bayne, supra note 91 , at 235. 
this point forward the Feldmann court is on a distinctly different path.

\section{The Culpability of the Parties}

But after some reflection, the mind becomes uneasy at an apparent inequity. True, the $M c$ Clure 15,000 dollars was, quite baldly, unjust recompense earned in a corporate act and properly belongs to the company. True, too, neither the premium-bribed should keep any of the 15,000 dollars nor should the premium-briber get any of it back. But hold, both Law and Levy were equally guilty. Yet Levy loses his full 15,000 dollars and Law remains unscathed, financially where he was in the beginning, able to walk away with a "nothing ventured nothing gained." The answer to this quandary can be found in several places.

The inequity will partially disappear with this realization: With the chips down, everybody involved really got exactly what they bargained for. The corporation got the 15,000 dollars, earned by its president on corporate time. The president himself was already getting his salary, and knew that any extras in the course of official business belonged in the corporate till. Even Mr. Levy, in a certain sense, got what he bargained for. He paid for a corporate act and he got it, even though not exactly as planned. Certainly he knew in his heart that a premium-briber could lose his premium-bribe.

(a) Damages Distinguished.-But any remaining inequity evanesces when an influential and oft-overlooked distinction is emphasized. Trial Judge Hincks put his finger on it. The disposition of the 2.1 million dollars and the various damages imposed for the multifaceted malefaction are deeply antithetical. Strictly, the question of damages is completely obiter to any discussion of premium-bribe disposition. But the legal mind cannot concentrate uninhibitedly on the disposition when flashes of inequity keep disturbing it. Interestingly, only two control courts, Gerdes ${ }^{123}$ and Bosworth, ${ }^{124}$ were able to concentrate on both damages and disposition at the same time. All the others were deflected to one or the other.

Since the premium-bribe damages is a question for elsewhere, ${ }^{125}$ only a summary is in order. But such summary should block damages from intruding into the disposition solution.

To say that damages are obiter to the disposition is perhaps an overstatement. Conceded, when the malefactors are

123. Gerdes v. Reynolds, 28 N.Y.S.2d 622 (Sup. Ct. 1941).

124. 168 N.Y. 157,61 N.E. 163 (1901).

125. Projected for answer in: The Sale-of-Control Premium: The Damages (forthcoming). 
nonshareholders-like Levy and Law-personal culpability ceases to be a factor after the litigation. But when malefactor shareholders later present their stock at the corporate window for a slice, either by dividends or redemption, of the original premium-bribe money, personal culpability cannot be ignored.

The present stratagem, therefore, is to carry forward with Levy and Law toward a complete judicial cleansing of culpability, both civil and criminal, in the thought that the final apportionment then can be faced in tranquil isolation. Assume therefore, ex hypothesi, that Mr. William H. Law has disgorged the 15,000 dollars to Life Union and that he and Mr. Louis P. Levy are about to be battered by antagonists in every conceivable suit, and all successful to a shuddering degree.

(i) Criminal.- Pursuant to the New York Penal Law the local district attorney initiates prosecution against Levy and Law for commercial bribing ${ }^{126}$ and commercial bribe receiving, ${ }^{12 \pi}$ which are both perfectly pat. Since Levy and Law were both guilty, as briber and bribed, of a class $B$ misdemeanor, the jury returns a verdict and each is fined and sentenced to prison for three months. ${ }^{128}$ The prison terms are identical, but with the fines the judge lets the punishment fit the crime: Levy 500 dollars, ${ }^{129}$ as briber, and Law 30,000 dollars, as bribed ("double the amount of the defendant's gain". ${ }^{131}$ ) Thus are inequities removed.

Since Mr. Law was also guilty under Penal Law Section $155.05^{131}$ of larceny by embezzlement, and Mr. Levy of conspiracy to commit the same crime, ${ }^{132}$ prosecution goes forward, with the same success: Fines of $\$ 500$ and three months in prison, ${ }^{133}$ consecutively served.

(ii) Civil.-Had Mr. David McClure, trustee for the Life Union, been able to study Gerdes and particularly Insuranshares, he would undoubtedly have initiated a tort action for, as Judge Hincks put it on the trial level in Feldmann, "the recovery of damages for harm done to the corporation by a breach of trust."' 134 Here after all is the cardinal sin of a trustee, clear disloyalty in the face of a conflict of interests. William Law, as outgoing, and Louis Levy, as incoming controleur, both assumed an identical obligation to promote the

\footnotetext{
126. See N.Y. PEN. LAW $\$ 180.00$ (McKinney 1967).

127. See id. $\$ 180.05$.

128. See id. $\$ \$ 60.10-2(\mathrm{~d}), 70.15-2$.

129. See id. \$ 80.05-2.

130. See id. \$80.05-5.

131. Id. \$ 155.05 .

132. See id.

133. Id. \$ 60.10-11(d).

134. 129 F. Supp. 162, 188 (D. Conn. 1952).
} 
corporate welfare. Yet in the all important appointment, both placed premium-bribe dollars before successor suitability. Here is serious malfeasance in office and the principal ingredient of the premiumbribe illegitimacy, the perversion of controleur judgment. For this "harm done to the corporation by a breach of trust," substantial-even punitive, considering the total helplessness of the corporation and the sensitive fiduciary duty of control-damages should be mulcted by the court.

But perversion was not the sole breach of trust. Both Levy and Law, again with equal culpability, foisted a premium-briber on Life Union, when both had pledged the best possible personnel for the future of the firm. This was not merely lack of due care but at the least the "substantial certainty" of section 8A (Intent) of the Restatement (Second) of Torts. ${ }^{135}$ The potential for disaster of a premium-briber in the top spot of Life Union was palpable, and damages should be awarded accordingly. (Had such a premium-briber been given a little time and latitude, as in Bosworth, ${ }^{136}$ Gerdes $^{137}$ and Insuranshares, ${ }^{138}$ this particular facet of the total turpitude-successor unsuitability-might show itself in further forms, e.g., the steel contracts Wilport might award Wilport.)

In paying over and retaining 15,000 dollars in illicit emolument, both Levy and Law again breached their fiduciary duty of loyalty, since personal welfare was placed before corporate. Such misappropriation of funds is clearly actionable.

But Mr. David McClure would not rest secure with tort liability alone. Under the pedestrian law of contract, the Levy-Law conspiracy would warrant further damages. Present in many aspects-including the 15,000 dollars-was a breach of the contract of hire under which Mr. Law agreed to devote his entire time, energies and abilities for the corporate benefit.

The court, in a summary review of the triple tort breach of trust, and the breach of contract, would hand down awards for example in the amount of 1,000 dollars on each of the several counts. (Surely a benign court would not be oblivious of the previous loss by Levy of the 15,000 dollars in premium-bribe money. As an ameliorative factor this would undoubtedly mitigate damages.)

(iii) Ouster.-As the final fillip, since Mr. McClure faced the Caplan-

135. Restatement (SECOND) OF ToRTs $\$ 8$ A (1965).

136. 168 N.Y. 157,61 N.E. 163 (1901).

137. 28 N.Y.S.2d 622 (Sup. Ct. 1941).

138. 35 F. Supp. 22 (E.D. Pa. 1940). 
Lionel $^{139}$ problem, surely he would have sought the permanent removal (as he probably did) of $\mathrm{Mr}$. Louis P. Levy from the office of controleur. Thus in Caplan-Lionel:

Therefore, some restrictions of the present board are required, so that the Sonnabend group may not take advantage of the position they hold. They shall be restricted to current management problems and other matters necessary for the proper functioning of the corporation and they shall not be permitted to use their present offices as the means to secure stockholder approval for their designated directorial slate, or dealing in matters involving self-interest, such as proposed acquisitions from Premier Corporation of America. ${ }^{1+0}$

But the broader subject of successor suitability is too far afield from the question of disposition. Suffice to say that some assurance of corporate protection from a premium-briber would permit the legal mind to focus unblurredly on the distribution of the premium-bribe money.

Thus, with criminal prosecutions, civil damages, removal from office, gone would be any lingering thought of an apparent inequity. Patently Mr. Law or any other controleur cannot exact his premiumbribe and take his chances. His day will come at other times in other courts. As will Mr. Levy's.

(b) The Philosophy in Globo.-Two fundamentals emerge from these reductiones ad absurdum. First, under the simple three-party McClure, involving a completely shareless sale, the 15,000 dollar payment over to the corporaton-whether through tort law alone or aided by restitution and trust-is founded exclusively on the illiceity of the consideration, with no admixture of either the controleur's perversion of judgment or the appointment of an unsuitable successor. Put in other words, the 15,000 dollars is illicit in and of itself and untainted by either perversion or successor unsuitability. Second, whatever personal culpability either Levy or Law incurred was completely cleansed away by the multifarious criminal and civil actions, climaxed by the disgorging of the 15,000 dollars itself. Both Levy and Law were as white as the driven lamb when they walked out of the last courtroom.

Thus reduced to the simplicity of $A$ to $B$ to $C$, and shorn of the confounding complexities of malefactor-owned shares, the basic philosophical principles point to a triple conclusion: The premiumbribe money goes in toto to the corporation. The premium-briber

139. 151 N.Y.L.J., Feb. 4, 1964, at 14, col. 3.

140. Id. at col. 6 . 
loses all. The premium-bribed retains nothing. Now the disposition can proceed into virgin territory-and directly contra to Feldmann. Perhaps, indeed, a Procrustes might have even stretched the Feldmann court this far. But not an inch farther.

Now that a hilltop view is possible, perhaps a little retrospect will aid appreciably in the progress of this study, for the reasoning has reached a high point and is starting downhill.

What the Feldmann court so fatefully failed to see, and what is so crucial, is the sharp division, the categorical splitting, of the broadest disposition question into two relatively unrelated subjects: (1) The philosophy supporting the unqualified award of the entire 2.1 million dollars directly to the corporation, thus: the original disposition to the corporation. (2) The basic principles governing the next stage, the apportionment by the corporation of that 2.1 million dollars so disposed, thus: the distribution after disposition. The shareless sale of $\mathrm{McCl}$ lure so aptly set off these distinct divisions.

The conclusions thus far have presumably settled the entire premium-bribe upon the corporation. The downhill road must now lead to a proper allocation by the corporation. Once in the corporation, how out of it?

\section{IV}

\section{The Distribution on Disposition}

The philosophical fundamentals, the shareless sale of McClure, tne thorough cleansing of Levy and Law, have supplied the wherewithal for just such an exact allocation of the 2.1 million dollars.

The apparent crux lies in Wilport's ownership of one-third of the Newport stock. But that only begins the problem. At three points the Feldmann court crashed head on with the philosophical fundamentals: (1) The corporation did not receive the entire 2.1 million dollars. (2) Feldmann did not disgorge all, only two-thirds. (3) Shareholder Wilport was denied its third.

The attempt at a settlement of this confrontation will proceed in two successive steps: (A.) The Eligibility to Share, (B.) The Severability of the Contracts.

\section{A. The Eligibility to Share}

The progress of the argument now finds Levy and Wilport, Law and Feldmann, arm in arm and fully purged, leaving the last of their many litigations. Perhaps the only difference in their respective 
hypothetical purgations would be caused by the relative enormity of the Wilport-Feldmann 2.1 million dollar malefaction.

Another supposition must be added to this hypothesis. Carry forward arguendo with the assumption so elaborately constructed thus far, that Feldmann, as Law, was ordered to pay over directly to the corporation the total 2.1 million dollars, not just two-thirds. Apart completely from intrinsic reasonableness this assumption has extrinsic support. Strict logic commands adherence to a general principle over a specific exception until such time as the general principle has been proven untenable. Philosophical fundamentals bolstered by the traditional rule in Sugden, ${ }^{141}$ McClure, ${ }^{142}$ Lionel, ${ }^{143}$ suggest that the entire premium-bribe belongs to the corporate entity until cogent countervailing reasons can be adduced. If none appear, the general principle prevails.

To reduce this hypothetical to its narrowest limits, further assume that the eventual ownership of the crucial one-third stock block (actually in Wilport's hands at the moment) remains undetermined. After later issues are resolved, possibly Feldmann will have the block. One thing only is certain at this point. None other than Feldmann or Wilport should receive this block's share of the 2.1 million dollars-neither the two-third public innocents by a windfall nor the state by escheat, unless by default.

The hypothesis of course has excluded the real business possibility that Newport might determine to use the 2.1 million dollars for debt retirement, plant expansion or any of many internal reasons. The present scrutiny is limited to the viability of the onethird block in the hands of either Feldmann or Wilport.

Another necessary oversight must be the possiblc control role of either Feldmann or Wilport after the stock has settled. Wilport's suitability for controleur of Newport-or even premium-bribed Feldmann's-does warrant further investigation. The distribution after disposition, however, concerns solely the eligibility to share in the 2.1 million dollars, and not the suitability to control the corporation. Whether a court should block Wilport, or Feldmann for that matter, from the office of control, as Lionel did Sonnabend, is a fascinating but collateral question.

With the field down to Feldmann and Wilport, how would dispassionate objectivity assess the eligibility of each to share in the

141. 3 Sm. \& G. 192, 65 Eng. Rep. 620 (1856).

142. 161 N.Y. 78,55 N.E. 388 (1899).

143. 151 N.Y.L.J., Feb. 4, 1964, at 14, col. 3 (Sup. Ct.). 
apportionment? Looking toward the day, under these circumscribed conditions, when either Feldmann or Wilport finally possess the controverted block, one can see only two apparent obstacles in their participation: (1) Such personal culpability as to render them unfit as individuals for any of the erstwhile premium-bribe money. (2) Such a taint on the shares as to preclude the stock itself, in anyone's hands, from any return of the 2.1 million dollars.

If Feldmann and Wilport can surmount these obstacles, they can enter the lists prepared to do battle over the rightful ownership of the one-third block. With Feldmann and Wilport, therefore, these obstacles will be faced successively.

\section{The Levy-Wilport Dilemma}

Both Mr. Levy and the Wilport Syndicate lost their 15,000 dollar and 2.1 million dollar premium-bribes. (In a wide sense both could be said to have disgorged, or less accurately "restored," them to the entity.) Both were completely battered with damages, fines, imprisonment. If nonshareholder, premium-briber Levy may now walk away cleansed, with no further obligation either to society in vindication or to the corporation in tort damages or trust "restitution," so certainly should a similar nonshareholder Wilport. And if a nonshareholder Wilport, why not also a shareholder Wilport? Even assuming a contrary-to-fact assumption that premiumbriber Wilport must always and forever be identified with shareholder Wilport, would not even a premium-briber shareholder Wilport be as fully rehabilitated as a premium-briber nonshareholder Levy? When shareholder Wilport presents his shares at the Newport window should he now be punished an additional 700,000 dollars? If so, should not Levy be called back and punished another third of 15,000 dollars? The dilemma is answerable in only one way. Once grant the justice and sufficiency of the punishment, damages and "restitution," and premium-briber Wilport disappears, to be supplanted by a new person, shareholder Wilport, untarnished.

The Levy-Wilport dilemma was used only because the disposition problem seems to center on the Wilport Syndicate. But everything said of Levy-Wilport is obviously applicable to Messrs. Law and Feldmann. Carrying out the same hypothetical, both disgorged their entire 15,000 dollars and 2.1 million dollars and both were fully cleansed. By the same valid argument, therefore, Mr. Feldmann as a possible shareholder could correspondingly share in any corporate disbursement of the 2.1 million dollars. Thus from the single aspect of a personal culpability, Levy and Wilport, Law and Feldmann should all be equally eligible to share. 


\section{The 15-10-15 Query}

Which leads opportunely to another apposite analogy and the question of tainted shares. Realign the pre-premium-bribe shareholdings of Feldmann and Wilport. As support for his mereincumbency control of Newport, Mr. Feldmann possessed a 25 percent block of stock. The Wilport Syndicate already held 15 percent. Again Feldmann and Wilport put their heads together, again agreed on the same 2.1 million dollar premium-bribe, but this time varied the script a bit-no doubt as an earnest of Feldmann's confidence in Wilport-by transferring only a ten percent block of Feldmann stock, at market. When the dust settled Wilport held 25 and Feldmann 15 percent.

Who now may come to the Newport window for a share of the 2.1 million dollars? Neither of the two 15 percent blocks-Feldmann's and the original Wilport-were involved directly in the so-called sale of control. Both blocks would hardly be barred at the distribution merely because their owners had otherwise indulged in a premiumbribe. One can conclude, thercfore, that the ownership itself or the mere holding could never indelibly taint the shares.

Patently any personal culpability of Feldmann or Wilport (even granting a residue) can scarce contaminate their stock. At worst the premium-bribe turpitude infected the human malefactors, not their nonhuman stock. This, of course, would be equally true of the ten percent block, at least to the extent that it was merely owned or held. The taint of owners, without more, can never taint the stock itself, whcther the two 15 percent blocks, the ten, or even the FeldmannWilport one-third.

All this may be true from the mere-ownership, personalculpability aspect, but the ten percent was more than merely held. It actually passed in connection with and at the time of the premiumbribe. Could such involvement in the deal bring ineradicable taint?

But was it actually involved? Recur to the shareless sale of Levy and Law. Embodied in that single deal was every evil possible to premium-bribery: The triple disloyalty of both Levy and Law in the perversion of judgment, the illicit consideration and the appointment of a premium-briber, and finally the retention of 15,000 dollars in corporate funds. Yet obviously none of this collective evil besmirched the shares that passed in connection with or at the time of the sale of control. Scarcely so, since no shares existed to pass. Clearly, then, the full maleficence of premium-bribery expresses itself without consequent effect on the stock. No causal nexus joins the collateral shares to the malefaction of premium-bribery. Total taint is possible 
without any shares at all. Thus, arguably, with shares actually present the taint is nonetheless fully pervasivc, but without pervading the shares.

But this at best is a negative proof. Consider the positive role of the ten percent in the act of premium-bribery. Was it the efficient cause? No, Wilport and Feldmann effected the deal. Material cause? That unhappy-but equally guiltless-role fell to the illicit consideration. Instrumental cause? lf any, it was the cold cash itself. The stock was neither the efficient cause nor the material cause nor the instrumental cause nor even the condition. Why? Because the stock-again witness Levy and Law-was not involved in the act of premium-bribery at all. It figured solely in a separate sale, collateral to an illegal act of premium-bribery. With no connection at all, hardly a causal connection.

All this, however, has only said why the shares are untainted, why the stock is not undeserving. Perhaps the correct approach is positive. The stock has a positiive right to share in the 2.1 million dollars, not because it was not involved in premium-bribery-which it was not-but because it-and all the blocks, the two 15 percent blocks and the ten - had beneath them an honest investment of cash. This cash earned a just return on a sudden but legal increment, also justly "earned" for the corporation by a hard-working employee in the course of his employment. The 2.1 million dollar increment should be available to all untainted shares alike.

Further support, if needed, could be garnered from the stock of Screw and Bolt's president. Any presidential shares would hardly be so tainted by the 20,000 dollar unearned emolument as to block a dividend resultant on that unexpected corporate increment.

Thus Feldmann and Wilport have successfully leaped the only two obstacles barring them from a welcome at the Newport window: (1) Personal culpability, seemingly long since purged, and (2) sullied shares now patently unsullied. All of which opens the lists for battle between two equally eligible combatants for the ownership of the unsullied shares. He who wins, Feldmann or Wilport, may legitimately claim one-third of the 2.1 million dollars. The ensuing analysis will confirm further the double eligibility-personal and shares-of Feldmann and Wilport.

\section{B. The Severability of the Contracts}

The nub of the sole remaining question is the legitimacy of the simple sale of stock. Was the Feldmann-Wilport deal an indivisible premium-bribe involving the transfer of a controlling block of stock 
for a single sum of 7.9 million dollars? ${ }^{144}$ Or did Feldmann and Wilport enter into two distinct contracts: (1) The sale of control by means of a 2.1 million dollar premium-bribe and (2) the sale of a onethird stock block at the market price of 5.8 million dollars? ${ }^{145}$

The fate of any contract of premium-bribery is beyond question. As a crime in some jurisdictions and a fraud on corporation and shareholders everywhere, such an agreement would be void ab initio and unenforceable on account of public policy. But when the contract of premium-bribery falls through invalidity, does it fall alone or carry down with it an inseparable sale of stock? If the stock sale can stand alone, Wilport keeps its shares, and a corresponding third of the 2.1 million dollars. If not, the stock block goes back to Feldmann and he gets the third.

\section{The Intent of the Parties}

Feldmann undoubtedly would argue that neither he nor Wilport ever envisaged anything but a single sale of a controlling block at a handsome price. In fact neither of them, so the story would go, would have ever entered into a simple stock sale without the surrender of the board. Wilport would counter with appropriate rebuttals, and the strong assertion that failing a control transfer the one-third block would nonetheless be more than a satisfactory beginning toward a legitimate 50-plus-percent majority. (Ironically the 2.1 million dollars would have just made the difference.) $)^{146}$

Feldmann undoubtedly would yield to the temptation to go all the way and allege his own crime of premium-bribery as the cause for invalidating the stock sale, with the resultant return of the shares to him. How a court would react to that, betimes.

But what the parties might have done had the invalidation been foreseen is gross conjecture. They contracted with other expectations. Since such conjectures on what might have been are otiose, the law must look at things as they actually were and conclude to the reasonable intent of the parties from all the circumstances surrounding the transaction.

In any attempt to penetrate to an unexpressed inteht of such a collateral agreement the court has a task with a double aspect. Whenever faced with intertwining contracts-one patently void the other not-the law as a rule, either rightly or wrongly, has

144. See Perlman v. Feldmann, I54 F. Supp. 436, 437 (D. Conn. 1957).

145. See id.

146. See id. 
correspondingly intertwined public-policy considerations with the strictly private rights of the parties. In facing such a complicated chore Levy and Law again should help somewhat. But the severability question requires more help than that. In the middle fifties two remarkably similar errants rode down an almost identical path. Their machinations and resultant litigation should elicit every needed principle toward the solution of this last remaining problem in the disposition of the 2.I million dollars.

\section{Kelly v. Kosuga ${ }^{14 \pi}$}

Like Levy and Law, Feldmann and Wilport before them, Jack H. Kelly and Vincent $W$. Kosuga had set themselves on a kindred criminal course, with only minor variations. Kelly and Kosuga "were both engaged in the marketing of onions," ${ }_{1+8}$ and unfortunately $\mathrm{Mr}$. Kosuga had grossly overstocked his inventory. Towards unloading several carloads of this oversupply, Kosuga and his friend, Sam Siegel, concocted a doubly duplicitous plan whereby they would not only sell off the excess onions but stabilize the market in the bargain.

By grossly overstating their supply-some "600 cars in the Chicago area and 400 more elsewhere throughout the country" and boldly threatening poor Kelly and friends with a massive unloading "on the futures exchange for the purpose of depressing the futures price and cash market price of onions' ${ }^{150}$ Kosuga and Siegel forced from hapless Kelly a contract of purchase for 50 carloads at 960 dollars per car. His friends took 237 more, "fearful that this [dumping] would cause them considerable loss." "151 Finally, all parties agreed, Kelly and friends on one side and the Kosuga-Siegel group on the other, that none would "deliver any of the onions ... on the futures market for the remainder of the season." "152 Admittedly, "this was "for the purpose of creating a false and fictitious market condition,' and 'to fix the price of onions and limit the amount of onions sold in the State of Illinois.' ',153

In the event, Kelly accepted some of the onions, made a payment or two on account, but finally reneged on 37 of the 50 cars. The onions began to rot and Kosuga "properly, after repudiation of the purchase by [Kelly], withdrew the remaining cars from storage and

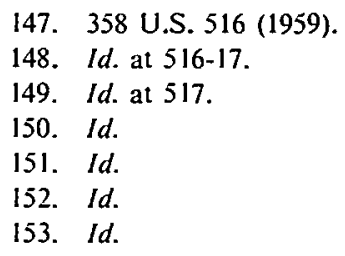


sold them for [Kelly's] account, . . . the market price having declined in the interim.' 154

The facts were undisputed. Kelly admitted buying the onions. He simply welshed on the deal, inspired possibly by the market drop. To this Vincent Kosuga reacted-much as Wilport arguably should have-by seeking court enforcement of the contract. Jack Kelly countered-much as Feldmann would have had he not got his third - "that the sale was made pursuant to and as an indivisible part of an agreement which violated $\S 1$ of the Sherman AntiTrust Act." "1.55

"The District Court entered summary judgment for the unpaid purchase price and storage charges, less the amounts obtained on the sale by" 156 Kosuga. The Court of Appeals for the Seventh Circuit affirmed. ${ }^{157}$ So also did the Supreme Court by Mr. Justice Brennan on "certiorari to consider the availability of the petitioner's pleaded defense of illegality under the Sherman Act to this action to enforce the terms of a sale made under state law." "'ss

To look at the final Feldmann problems through the eyes of Kosuga is eminently justified. The two cases are on all fours on the question of severability, with the marked difference that Feldmann never reached the problem, while Kosuga faced it with success.

Yet "severability" is not an exact description of the question. As Justice Brennan said: "[A]nalysis in terms of 'divisibility' or some other verbal formula may well be circular.' 159 Deeper down, both Feldmann and Kosuga faced a far more basic question: Was the contract of sale, stock or onions, a viable unit? Can it, should it, stand alone on its own? Or must it fall with the concomitant criminal contract, the premium-bribery, the price fixing?

The several principles underlying the problem of viability-some directly adduced by the Kosuga court, some hinted at, others skirted-are an intriguing blend of the public and the private, the intrinsic and the extrinsic, the positive and the negative. Hand in hand with the Kosuga court these principles will be dissected and evaluated.

\section{The Presumption of Viability}

In such a technical inquiry one might overlook inadvertently an elemental principle of law and human conduct. When two rational

154. Id. at 518 .

155. Id. at 516 .

156. Id. at 518 .

157. 257 F.2d 48 (1958).

158. 358 U.S. at 518.

159. Id. at 521 . 
and reflective persons enter an important agreement they generally have every intention of carrying through with it. An understandable presumption has developed over the history of contracting man that contracts are to be carried out, and that the law should enforce them without clear reason to the contrary. Hence cogent argument must be adduced to invalidate either the purchase of the onions or the sale of Feldmann's stock. Why not assume that the parties meant what they said? The Kosuga court was not far from this presumption: "[T]he federal courts should not be quick to create a policy of nonenforcement of contracts beyond that which is clearly the requirement of the Sherman Act." 160 As succeeding arguments are marshalled, therefore, bear in mind that the original, expressed intent should not be subverted for a slight reason.

But presumptions and extrinsic arguments aside, the overriding argument for the severability of the sale contracts from the premiumbribery and price fixing lies in the elementary analysis of the causal connection between the two. Levy and Law demonstrated the possibility of producing all the evils of premium-bribery without any stock sale at all. Kelly, Kosuga and Siegel could have cornered the market without ever an onion changing hands. A simple agreement to hold their onions from the market would have done the trick. And certainly Mr. Feldmann could have entrusted control of Newport to Wilport without any concomitant stock, as old man Weyenberg virtually did when he installed Florsheim as controleur of Weyenberg Shoe. (Florsheim bought a negligible three percent at market.) ${ }^{161}$ Clearly, then, in no instances was there any causal connection between the criminal malefactions and any accompanying sales. The sole question in Kosuga and Feldmann was the nature of the noncausal connection, tenuous as it was. Since not a cause, was the sale a condition, a sine qua non to the price fixing? Note again that the cornering operation admittedly could have succeeded without any purchase. Nor was the Feldmann-Wilport sale of stock any more intimately connected with the premium-bribery. Not only were the sales not causes of the crimes, they were not even conditions.

Undoubtedly, however, in both Feldmann and Kosuga there was some connection between contracts and malefactions. But the connection was only of time and place, mere accidentals in no way integral to the respective agreements. The stock block could have been sold many months before, or after, the premium-bribery, since control

160. Id. at 519 .

161. See note 38 supra. 
of Newport was referable to the proxy and the wide dispersal of shares. So too with the onions and the price fixing. Mr. Justice Brennan could have been speaking for Feldmann as well as Kosuga when he described the true nature of the connection:

[W]e do not think it inappropriate or violative of the intent of the parties to give [the sale] effect even though it furnished the occasion for a restrictive agreement of the sort here in question. ${ }^{162}$

In short here were two completely separate deals. In Kosuga it suited Kosuga's purpose to unload some onions. With Feldmann some stock. As for Wilport, substantial stock support for an anticipated mere-incumbency control position, or a beginning toward a majority, was not an undesirable thought. As for Kelly, he was bludgeoned into the deal, but nonetheless as a marketer could use the onions. Or so he thought. The price fixing and the premium-bribery were other matters indeed.

The Kosuga court adduced another positive argument in support of viability. Taken in complete isolation, as separate deals in their own right, the sales, onions and stock, both represented completely integral agreements in themselves, with lawful terms, commendable purpose, honest price. Nothing within the four corners could evoke attack, let along invalidation. Hence, the Supreme Court saw no reason not

to give legal effect to a completed sale of onions at a fair price. And while analysis in terms of "divisibility" or some other verbal formula may well be circular, . . . in any event, where, as here, a lawful sale for a fair consideration constitutes an intelligible economic transaction in itself, we do not think it inappropriate or violative of the intent of the parties to give it effect .....$^{163}$

\section{Public Protection}

The public-policy arguments for invalidating such collateral contracts are necessarily founded on one overriding purpose: the protection of the public. In an excess of zeal one may forget that public protection is never needed without something to protect the public from. If a private contract offers no public threat, public policy should scarce be invoked. The entire discussion of enforceability or severability or divisibility, therefore, could have stopped logically with the intrinsic arguments. If a contract of sale of onions or stock is good in itself, no need for speculation on the harm such a contract

162. 358 U.S. at 521 (emphasis added).

163. Id. 
could inflict on the public. If no intrinsic wrong, no need for extrinsic measures of protection. Of all the concepts supporting severability, the Kosuga court relied most on this distinction between private contract and public protection, between intrinsic legitimacy and extrinsic factors, between positive and negative arguments. In his concluding statement Mr. Justice Brennan summarized this dichotomy:

Accordingly, while the nondelivery agreement between the parties could not be enforced by a court, if its unlawful character under the Sherman Act be assumed, it can hardly be said to enforce a violation of the Act to give legal effect to a completed sale of onions at a fair price. ${ }^{164}$

Which of course could be said equally of the premium-bribery agreement and "a completed sale of [stock] at a fair price."

The negative norm for a court in such circumstances is extremely limited. In Continental Wall Paper Company v. Louis Voight \& Sons, Company $y^{165}$ the allegedly legal purchases were integral to the price fixing:

The Court was of opinion that to give judgment for the excessive purchase price so fixed in favor of such a vendor would be to make the courts a party to the carrying out of one of the very restraints forbidden by the Sherman Act [citation omitted]. Any thought that the Court might have been proceeding on broader grounds was shortly afterwards laid to rest by the unanimous opinion of the Court in the Wilder case [citation omitted]. The scope of the defense of illegality under the Sherman Act goes no further. ${ }^{166}$

Scant danger of becoming a party to the crime faced the Feldmann court in giving Wilport the returns on its stock.

The civil court has no business in assuming the role of a public prosecutor. Mr. Justice Brennan carried this thesis to its logical conclusion: "The Court [again in the Wilder case] observed that the Sherman Act's express remedies could not be added to judicially by including the avoidance of private contracts as a sanction." 167 How apropos of Mr. Levy, and correspondingly the Wilport Syndicate. If fine and imprisonment were efficacious, if tort damages for the perversion, successor unsuitability and illicit consideration were sufficient, if the 2.1 million dollar premium-bribe was lost for good, should the Feldmann court add judicially a further sanction by the

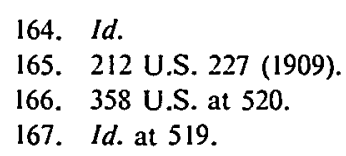


denial of a just share in the corporate increment? "Supplying a sanction for the violation of the Act, not in terms provided and capricious in its operation . . . is avoided by treating the defense [of illegality] as so confined [to cases where the courts would become a party to the crime]." 168

If the court's role is so limited, a fortiori it ill behooves the corporation (should the matter not reach litigation) to assume the court's mantle by withholding a stockholder's proportionate share. Even were damages never mulcted or fines imposed, the corporation arguably would have no right to rectify the omission in this collateral way.

The Kosuga court became understandably wroth-as the Feldmann court should have with Feldmann-when Kelly alleged his own crime in defense of his own breach of contract. "It has been often stated in similar cases that the defence is a very dishonest one, and it lies ill in the mouth of the defendant to allege it, and it is only allowed for public considerations and in order the better to secure the public against dishonest transactions." "169 If court and corporation relegate to the proper parties the crime, the damages and the restitution, what must be said of the malefactor who himself refuses so to act? "If the defense of illegality is to be allowed as a collateral method of enforcement of the antitrust laws, as the breadth of [Kelly's] argument suggests, it must be said that his theory creates a very strange class of private attorneys general." ${ }^{170}$

The Kosuga Court touched briefly on the irrelevancy to a collateral contract action of any personal culpability of the parties. "While enforcement of a contract between wrongdoers may more frequently present such a situation ... the character of the parties is not in itself determinative."'171

Thus the final anomaly of Feldmann emerges. In letting Wilport keep its shares the court correctly approved the contract of sale, but in denying Wilport any returns on the stock, it reprobated it. If the stock sale was legitimate, why emasculate the stock and leave Wilport's 780,000 dollar portion with Feldmann? (Premium-bribed Feldmann, to boot.)

\section{The End of the Hypothetical}

With this the matter seems concluded. The traditional law of

168. Id. at 521 .

169. Id. at 519 .

170. Id. at 520 .

171. Id. 
Sugden ${ }^{172}$ and $\mathrm{McClure}^{\mathrm{173}}$ would have awarded the 2.1 million dollars directly to Newport Steel. Since premium-briber Wilport was personally purged, since the stock itself was untainted, and since the contract of sale was judicially severed from the collateral premiumbribery, shareholder Wilport would be welcomed at the Newport window for its portion of the 2.1 million dollars-now no doubt long since spent by $\mathrm{Mr}$. Feldmann and his friends.

\section{CONCLUSION}

Perlman v. Feldmann, enhanced by its historic acclaim, has undoubtedly been the perfect incentive to a full analysis of the premium-bribe disposition. It laid out the basic truths so well, as an encouragement to begin, yet intriguingly left so much undone, as a challenge to carry on. Any elusive questions still out of the box are a chore for the future.

172. 3 Sm. \& G. 192, 65 Eng. Rep. 620 (1856).

173. 161 N.Y. 78,55 N.E. 388 (1899). 